\title{
Combination therapy with catechins and caffeine inhibits fat accumulation in 3T3-L1 cells
}

\author{
XIAOJUAN ZHU, LICONG YANG, FENG XU, LEZHEN LIN and GUODONG ZHENG \\ Jiangxi Key Laboratory of Natural Product and Functional Food, College of Food Science and Engineering, \\ Jiangxi Agricultural University, Nanchang, Jiangxi 330045, P.R. China
}

Received August 13, 2015; Accepted September 27, 2016

DOI: $10.3892 /$ etm.2016.3975

\begin{abstract}
Catechins and caffeine, which are green tea components, have a slimming effect; however, the combinational effect of fat metabolism in 3T3-L1 cells remains unclear. In the present study, 3T3-L1 cells were treated with catechins and caffeine in combination, and it was found that combination therapy with catechins and caffeine markedly reduced intracellular fat accumulation, mRNA expression levels of peroxisome proliferator-activated receptor- $\gamma$ and CCAAT/enhancer-binding protein $\alpha$ in the early stage of cell differentiation were significantly reduced, and mRNA expression of fatty acid synthetase (FAS) and glycerol-3-phosphate dehydrogenase protein expression levels of FAS were downregulated. Noradrenaline-induced lipolysis was enhanced by caffeine, which markedly increased the protein expression of adipose triglyceride lipase and hormone sensitive lipase. These results indicated that combination therapy with catechins and caffeine synergistically inhibited lipid accumulation by regulating the gene and protein expression levels of lipid metabolism-related enzymes. Therefore, catechins and caffeine combination therapy has potential as a functional food that may be used to prevent obesity and lifestyle-associated diseases.
\end{abstract}

Correspondence to: Dr Guodong Zheng, Jiangxi Key Laboratory of Natural Product and Functional Food, College of Food Science and Engineering, Jiangxi Agricultural University, 1101 Zhimin Road, Nanchang, Jiangxi 330045, P.R. China

E-mail: zrs150716@aliyun.com

Abbreviations: ATGL, adipose triglyceride lipase; C/EBP $\alpha$, CCAAT/enhancer binding protein $\alpha$; FAS, fatty acid synthetase; GPDH, glycerol-3-phosphate dehydrogenase; HSL, hormone sensitive lipase; PPAR $\gamma 2$, peroxisome proliferator-activated receptor $\gamma 2$; TG, triglyceride

Key words: 3T3-L1, caffeine, catechins, lipogenesis, lipolysis

\section{Introduction}

Obesity, which is a disease characterized by the excessive accumulation of triglyceride (TG), manifests as adipocytes that increase in size and number accompanied by lipolysis damage in adipose tissue. Obesity has become a global hazard to human health, and is also a major public health concern that inflicts an increasing financial burden on numerous countries (1). Human and animal studies have demonstrated that obesity is associated with multiple chronic metabolic disorders, including hypertension, certain types of cancer, cardiovascular disease, type 2 diabetes mellitus and dyslipidemia (2-5). These associations rely on the excessive differentiation and growth of adipocytes, the main constituent of fat, which leads to increased fat cell mass and number, surplus energy accumulation stored as TG in adipocytes, and adipogenesis, which includes structural changes lipid accumulation and lipogenic enzyme expression (6). The main therapeutic agents for obesity are orlistat and sibutramine hydrochloride, both of which are known to have toxic side effects $(7,8)$. Therefore, it is important that efforts are made to seek an effective and secure natural product to inhibit or delay the occurrence of obesity.

Animal studies have indicated that certain plant extracts and their respective bioactive components may have direct effects on adipose tissue, and their synergistic or additive effects have been investigated (9). Total isoflavones from P.lobata significantly inhibited the increase in body weight and lipoprotein levels, furthermore puerarin decreased body and intraperitioneal adipose tissue weight $(10,11)$. Adipose tissue is a dynamic metabolic and endocrine organ that has a vital role in energy homeostasis, which regulates preadipose cell growth, adipocyte differentiation and lipogenesis (12). Adipose tissue is predominantly composed of adipocytes, and 3T3-L1 adipocytes have been recognized as a classic model of fat metabolism (13). Following induction, 3T3-L1 preadipocytes differentiate into mature adipocytes, the process of which consists of changes in cell morphology, transcription factors and lipid metabolism-related enzymes; therefore, it can provide a well-established model of adipocyte differentiation at the cellular level (14). Consequently, the inhibition of TG accumulation in 3T3-L1 cells may be of crucial therapeutic importance to treating obesity.

Green tea is one of the most popular drinks in Asia, and drinking tea regularly is beneficial to weight loss (15). 
Studies have revealed that physiological functions of green tea include antioxidative, anti-inflammatory and anti-cancer effects, and type 2 diabetes mellitus prevention (3). Therefore, intake of green tea is effective in lowering total cholesterol (TC) and low-density lipoprotein cholesterol concentrations in adults (16), reducing body weight, body mass index (BMI) and waist circumference in the elderly with metabolism syndrome (17). Catechins and caffeine are the main functional components in green tea. Caffeine content in green tea is $1-5 \%$ (18), whereas catechins may constitute up to $30 \%$ of the dry weight (19). Catechin- and caffeine-rich teas have the potential to have a significant impact on fat absorption and energy intake (20). Catechins have been demonstrated to reduce the levels of TG and TC in serum and liver (21), and higher catechin intake is associated with a lower BMI increase in women who have been drinking tea for $>14$ years (22).

Catechins and caffeine effectively stimulate thermogenesis by relieving inhibition at various control points along the noradrenaline-cAMP axis in rats (23). In a previous study, catechins and caffeine significantly reduced body weight increases and the weight of intraperitoneal adipose tissues compared with control mice (24). Green tea extract has thermogenic properties and/or promotes fat oxidation, which may be responsible for the control of body composition that has been documented in humans (25). Despite the widespread use of catechins and caffeine, the combinational effect of catechins and caffeine has rarely been reported in 3T3-L1 cells, and the mechanism of its therapeutic effect has not been elucidated. In the present study, the effect of combination therapy with catechins and caffeine was investigated in differentiated 3T3-L1 cells, including analysis of lipid accumulation in the treated cells, genes expression levels of adipocyte-specific enzymes, including fatty acid synthetase $(F A S)$, glycerol-3-phosphate dehydrogenase $(G P D H)$, and adipogenic transcriptional factors, including peroxisome proliferator-activated receptor $\gamma$ $(P P A R \gamma)$ and CCAAT/enhancer-binding protein $\alpha(C / E B P \alpha)$, and protein expression of FAS, adipose triglyceride lipase (ATGL) and hormone sensitive lipase (HSL).

\section{Materials and methods}

Reagents. Newborn calf serum (NBCS), fetal bovine serum (FBS) and Dulbecco's modified Eagle's medium (DMEM) were purchased from Gibco (Thermo Fisher Scientific, Inc., Waltham, MA, USA). Insulin, dexamethasone, isobutylmethylxanthine and noradrenaline (NA) were obtained from Sigma-Aldrich (Merck Millipore, Darmstadt, Germany). Antibodies against ATGL (2138S) and HSL (4107S) were purchased from Cell Signaling Technology, Inc., (Danvers, MA, USA). FAS antibody (sc-1023) was purchased from Santa Cruz Biotechnology, Inc. (Dallas, TX, USA), $\beta$-actin antibody (TA-09) and secondary antibodies (ZB-2305Mo and ZB-2301Rb) were purchased from Zhongshan Golden Bridge Biotechnology Co., Ltd., (Beijing, China).

Cell culture and differentiation. 3T3-L1 cells were obtained from KeyGEN Biotechnology (Nanjing, China). Cells were cultured in a humidified atmosphere containing $5 \% \mathrm{CO}_{2}$ at $37^{\circ} \mathrm{C}$ in DMEM supplemented with $10 \%$ NBCS. Two days after confluence, 3T3-L1 preadipocytes were differentiated into adipocytes by changing to $10 \%$ FBS DMEM supplemented with $5 \mathrm{mg} / \mathrm{ml}$ insulin, $0.25 \mu \mathrm{mol} / 1$ dexamethasone and $0.5 \mathrm{mM}$ isobutylmethylxanthine for $48 \mathrm{~h}$ (defined as day 0). Subsequently, the cells were placed in the same medium containing $5 \mathrm{mg} / \mathrm{ml}$ insulin, but lacking any other supplements for an additional 2 days. Following this, the cell medium was replaced with DMEM containing $10 \%$ FBS, and was replenished every 2 days until more than $90 \%$ of cells were mature adipocytes with accumulated fat droplets, as identified under a light microscope. To examine the effects of combination therapy with catechins and caffeine on adipogenesis, 3T3-L1 adipocytes were treated with various concentrations of systematic catechins and caffeine: $40 \mu \mathrm{g} / \mathrm{ml}$ catechins (group I), $160 \mu \mathrm{g} / \mathrm{ml}$ caffeine (group II), control (group III), $80 \mu \mathrm{g} / \mathrm{ml}$ caffeine $+10 \mu \mathrm{g} / \mathrm{ml}$ catechins (group IV), $160 \mu \mathrm{g} / \mathrm{ml}$ caffeine $+10 \mu \mathrm{g} / \mathrm{ml}$ catechins (group V), $80 \mu \mathrm{g} / \mathrm{ml}$ caffeine $+20 \mu \mathrm{g} / \mathrm{ml}$ catechins (group VI), $160 \mu \mathrm{g} / \mathrm{ml}$ caffeine $+20 \mu \mathrm{g} / \mathrm{ml}$ catechins (group VII), $80 \mu \mathrm{g} / \mathrm{ml}$ caffeine $+40 \mu \mathrm{g} / \mathrm{ml}$ catechins (group VIII), $160 \mu \mathrm{g} / \mathrm{ml}$ caffeine $+40 \mu \mathrm{g} / \mathrm{ml}$ catechins (group IX) at the time of induction period (days 0-4).

Oil Red $O$ staining. Lipid accumulation was determined to mirror the degree of differentiation at day 8 by Oil red $\mathrm{O}$ staining. Cells were washed twice with PBS at pH 7.4 and subsequently fixed with $10 \%$ formalin for $30 \mathrm{~min}$ at room temperature. Following washing with distilled water twice, cells were completely dried before staining with $0.5 \%$ Oil Red $\mathrm{O}$ for $1 \mathrm{~h}$. Thereafter, the stained cells were washed three times with distilled water, and representative images of treated cells were obtained with an inverted microscope (magnification, $\mathrm{x} 400)$.

Determination of TG level. 3T3-L1 cells were seeded in 24-well plates and incubated in the presence of various concentrations of catechins and caffeine in combination as described. Adipocytes were washed with PBS at day 8 after the initiation of differentiation, and cell lysis reagent were added into each well and incubated for $15 \mathrm{~min}$. The lysate was transferred to a new Eppendorf tube, heated at $70^{\circ} \mathrm{C}$ for $10 \mathrm{~min}$, centrifuged $\left(1,000 \mathrm{xg} ; 4^{\circ} \mathrm{C} ; 10 \mathrm{~min}\right)$, and the cellular TG content was subsequently determined using a commercial triglyceride assay kit (Applygen, Beijing, China). According to the manufacturer's protocol, absorbance was detected at $570 \mathrm{~nm}$ and quantified using a spectrophotometric microplate reader.

Reverse transcription-quantitative polymerase chain reaction (RT-qPCR). Total RNA was extracted from 3T3-L1 cells with TRIzol reagent (TransGen Biotech, Beijing, China) in accordance with the manufacturer's protocol. cDNAs were synthesized using a SuperScript First-Strand Synthesis system kit (Invitrogen; Thermo Fisher Scientific, Inc.). All primer sequences used were as follows: $C / E B P \alpha$, forward 5'-CGC AAGAGCCGAGATAAAGC-3' and reverse 5'-GAGATC CAGCGACCCGAA AC-3'; FAS, forward 5'-CAAGTG TCCACCAACAAGGCG-3' and reverse 5'-GATGCCGTC AGGTTTCAGT-3'; GPDH, forward 5'-TGTGTCCGTCGT GGATCTGA-3' and reverse 5'-CCTGCTTCACCACCT TCTTGA-3'; PPAR $\gamma 2$, forward 5'-CCACTCGCATTCCTT 
TGAC-3' and reverse 5'-CCACAGACTCGGCACTCAAT-3'; $\beta$-actin, forward 5'-CTGTCCCTGTATGCCTCTG-3' and reverse 5'- ATGTCACGCACGATTTCC-3'. Reaction conditions were as follows: preheated at $95^{\circ} \mathrm{C}$ for $3 \mathrm{~min}, 35$ cycles of $94^{\circ} \mathrm{C}$ for $30 \mathrm{sec}, 55-65^{\circ} \mathrm{C}$ for $30 \mathrm{sec}$ and $72^{\circ} \mathrm{C}$ for $40 \mathrm{sec}$, followed by $72^{\circ} \mathrm{C}$ for $10 \mathrm{~min}$. Quantification was achieved using the $2^{-\Delta \Delta C q}$ method (26), which calculates the relative changes in gene expression of the target normalized to $\beta$-actin. The intensity of the PCR products on the agarose gel was measured with ImageJ image analysis software (National Institutes of Health, Bethesda, MA, USA).

Western blot analysis. 3T3-L1 cells were cultured for 8 or 12 days in the absence or presence of catechins and caffeine as described above. At day 12, each group was incubated with or without $0.1 \mu \mathrm{g} / \mathrm{ml}$ noradrenalin in phenol red-free DMEM without serum for $24 \mathrm{~h}$. Mature 3T3-L1 cells were washed twice with cold PBS and scraped into lysis buffer for $10 \mathrm{~min}$. The cell mixture was centrifuged at $12,000 \mathrm{x}$ g for $5 \mathrm{~min}$ at $4^{\circ} \mathrm{C}$, and the supernatant was preserved in liquid nitrogen until western blotting. An aliquot containing $30 \mu \mathrm{g}$ supernatant protein was separated by $0.1 \%$ SDS-PAGE and subsequently transferred onto polyvinylidene fluoride membrane with Transfer film buffer. The membrane was blocked for $2 \mathrm{~h}$ at room temperature with $10 \mathrm{mM}$ PBS containing $0.1 \%$ Tween 20 and 5\% nonfat milk. Following washing with Tris buffered saline with Tween 20 (TBST), membranes were incubated with anti-FAS, anti-ATGL antibody, anti-HSL and anti- $\beta$-actin primary antibodies (all 1:1,000) at $4^{\circ} \mathrm{C}$ overnight. Subsequently, they were washed three times with TBST for 5 min followed by incubation with the secondary antibody at a dilution of 1:2,000 for $1 \mathrm{~h}$ at room temperature. Bands were detected by chemiluminescent substrate and protein expression was quantified using VWLS 7.0.1 software (UVP, Inc., Upland, CA, USA). Intracellular proteins were quantified and normalized to $\beta$-actin, and expressed as a percentage of the control.

Statistical analysis. Data were presented as mean \pm standard error, and all determinations were repeated four times. Statistical analysis was performed using one-way analysis of variance with the SPSS 10.0 statistical software package (SPSS Inc., Chicago, IL, USA). P $<0.05$ was considered to indicate a statistically significant difference.

\section{Results}

Combinational effects of catechins and caffeine on lipid accumulation in 3T3-L1 cells. Oil Red O staining results showed that combination therapy with catechins and caffeine markedly inhibited cell differentiation. Moreover, it was demonstrated that the higher the concentration of catechins in the combination, the stronger the inhibitory effect on fat synthesis (Fig. 1A). As shown in Fig. 1B, compared with the control, the TG content of groups I, V, VI, VII, VIII and IX were reduced by 24.4, 28.8, 26.1,31.8, 40.7 and $51.7 \%$, respectively $(\mathrm{P}<0.05)$. When administered alone, caffeine exhibited no obvious change in intracellular TG levels, whereas the other groups containing catechins markedly inhibited lipid accumulation. These data indicated that reduced fat deposi- tion was responsible for the anti-adipogenic effect induced by combination therapy with catechins and caffeine in 3T3-L1 cells. When catechins in combination remained the same and the caffeine concentration increased, TG content was lower in 3T3-L1 cells, indicating that 3T3-L1 adipocytes treated with catechins and caffeine in combination exhibited a dose-dependent decrease in TG content.

Combinational effects of catechins and caffeine on gene expression levels in 3T3-L1 cells. PPAR $\gamma$ and $\mathrm{C} / \mathrm{EBP} \alpha$ coordinately activate the entire program of differentiation in adipocytes (27); therefore, the effect of combinational catechins and caffeine on the mRNA expression levels of $P P A R \gamma 2$ and $C / E B P \alpha$ was examined (Fig. 2). Combination therapy with catechins and caffeine markedly suppressed the gene expression of $P P A R \gamma 2$ and $C / E B P \alpha$ in the early stage of adipogenesis, particularly in cells treated with the combination of $40 \mu \mathrm{g} / \mathrm{ml}$ catechins. These results suggested that combination therapy with catechins and caffeine may arrest cell differentiation by reducing the mRNA expression of $P P A R \gamma 2$ and $C / E B P \alpha$ in 3T3-L1 cells. As observed in Fig. 3A, catechins and caffeine in combination significantly affected FAS mRNA expression; notably, the inhibitory effect was directly proportional to the catechin concentration. Compared with the control, GPDH mRNA expression levels in I, VIII and IX were decreased by $22.45,24.39$ and $25.21 \%$, respectively ( $\mathrm{P}<0.05$; Fig. 3B).

Combinational effects of catechins and caffeine on protein expression levels in 3T3-L1 cells. The present findings demonstrated that exposure of 3T3-L1 cells to different concentrations of catechins and caffeine in combination decreased the protein expression level of FAS, particularly in cells treated with $40 \mu \mathrm{g} / \mathrm{ml}$ catechins at day 8 . Catechins and caffeine in combination have a synergistic effect on FAS expression, as indicated by the findings that FAS expression levels in groups I, VIII and IX were decreased by 30.25 , 31.56 and $37.73 \%$, respectively (Fig. 4). The addition of NA significantly increased the protein expression levels of HSL (Fig. 5A; P<0.05) and ATGL (Fig. 5B; $\mathrm{P}<0.05$ ) in all the groups. Compared with NA, caffeine therapy had a marked role in increasing the protein expression levels of HSL and ATGL (P<0.05; Fig. 5).

\section{Discussion}

The present study demonstrated that combination therapy with catechins and caffeine may significantly reduce fat accumulation in 3T3-L1 cells. Epigallocatechin-3-gallate (EGCG), which is one of the main catechins of green tea, has been reported to decrease intracellular fat accumulation after incubation with $10 \mu \mathrm{M}$ EGCG for $24 \mathrm{~h}$, and increase the amount of glycerol released in the medium in 3T3-L1 cells (28). 3T3-L1 cells treated with $50 \mu \mathrm{mol} / 1$ caffeine exhibited significantly reduced fat accumulation in another previous study (29). Furthermore, catechins reduced the level of TG in the liver, and combination therapy with catechins and caffeine reduced body weight gain and intraperitoneal adipose weight in mice (24). In vivo, a previous study indicated that the combination of catechins and caffeine inhibited fat accumulation, which is consistent with 
A

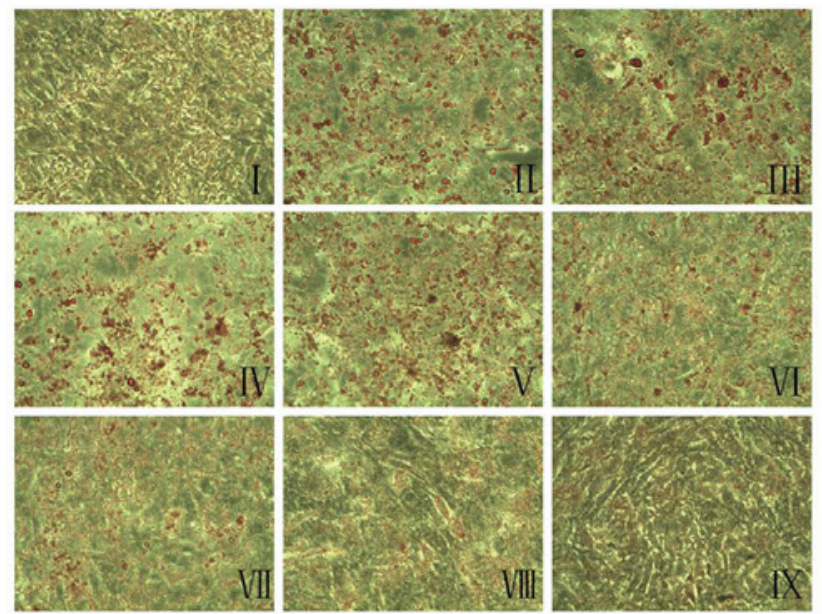

B

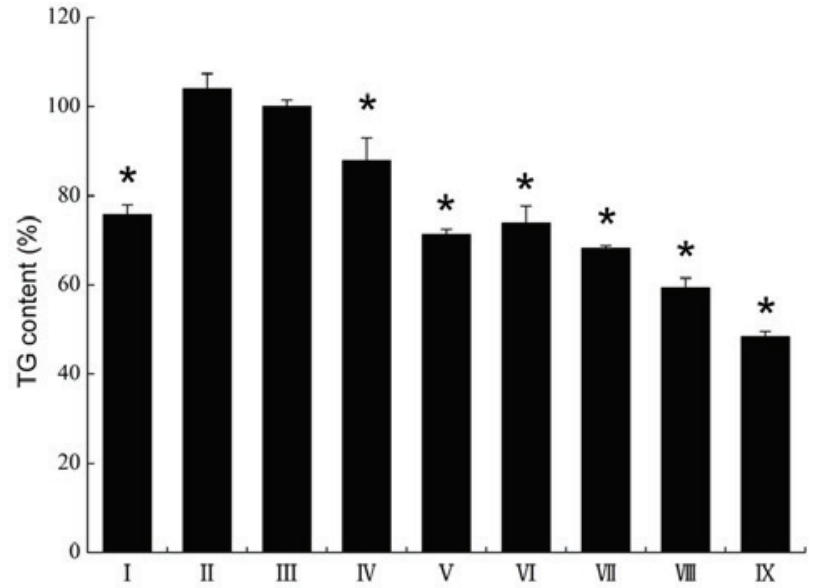

Figure 1. Effects of combination therapy with catechins and caffeine on TG accumulation in 3T3-L1 adipocytes. (A) Representative images of Oil Red O-stained cells captured at day 8 using an inverted microscope (magnification, x400). (B) Fat accumulation was determined by intracellular TG content, and expressed as a percentage relative to the control, which was taken as $100 \%$. Data are presented as the mean \pm standard error $(\mathrm{n}=4)$. Different letters indicate samples that are significantly different ("P<0.05). TG, triglyceride; I, $40 \mu \mathrm{g} / \mathrm{ml}$ catechins; II, $160 \mu \mathrm{g} / \mathrm{ml}$ caffeine; III, control; IV, $80 \mu \mathrm{g} / \mathrm{ml}$ caffeine $+10 \mu \mathrm{g} / \mathrm{ml}$ catechins; $\mathrm{V}, 160 \mu \mathrm{g} / \mathrm{ml}$ caffeine $+10 \mu \mathrm{g} / \mathrm{ml}$ catechins; VI, $80 \mu \mathrm{g} / \mathrm{ml}$ caffeine $+20 \mu \mathrm{g} / \mathrm{ml}$ catechins; VII, $160 \mu \mathrm{g} / \mathrm{ml}$ caffeine $+20 \mu \mathrm{g} / \mathrm{ml}$ catechins; VIII, $80 \mu \mathrm{g} / \mathrm{ml}$ caffeine $+40 \mu \mathrm{g} / \mathrm{ml}$ catechins; IX, $160 \mu \mathrm{g} / \mathrm{ml}$ caffeine $+40 \mu \mathrm{g} / \mathrm{ml}$ catechins.
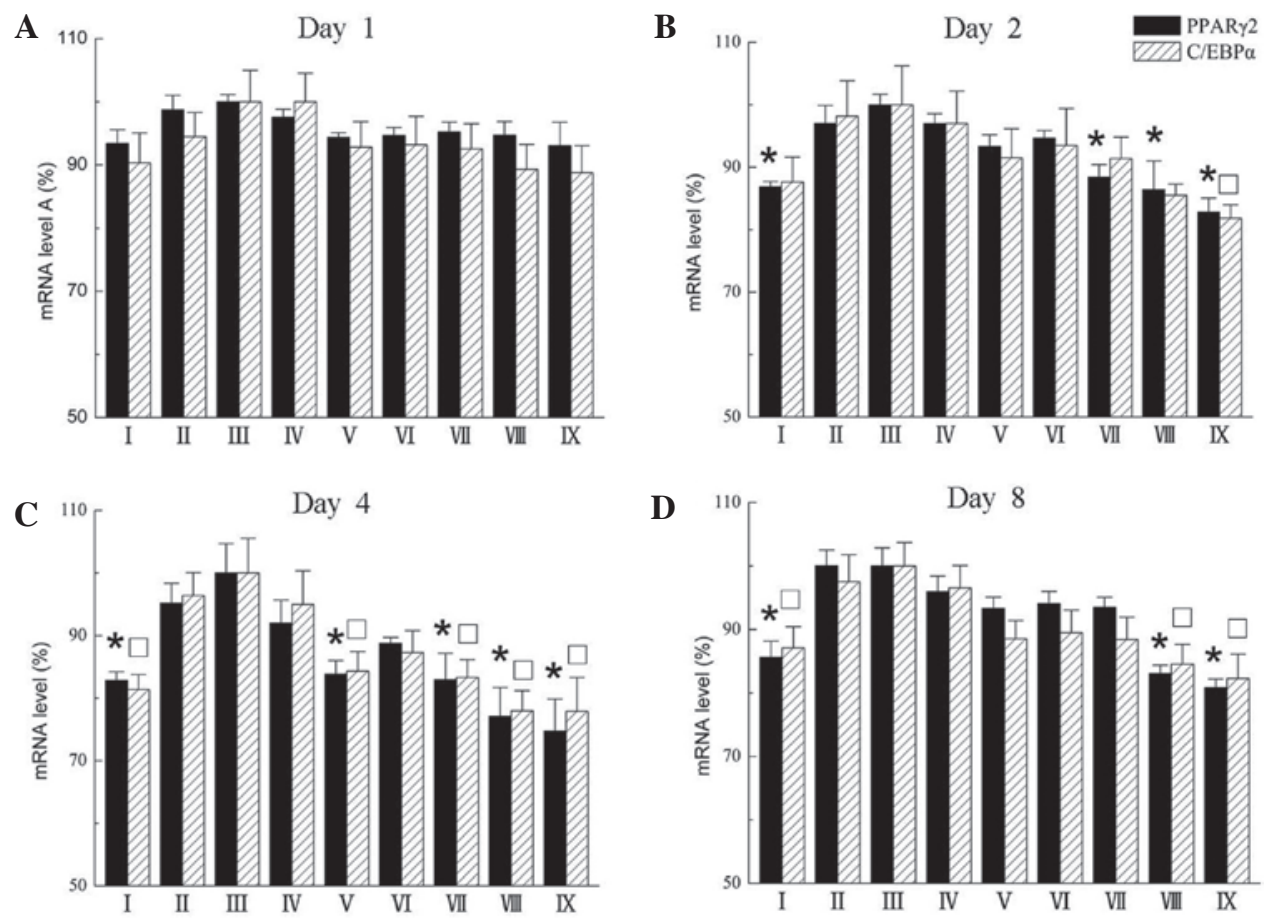

Figure 2. Effects of combination therapy with catechins and caffeine on mRNA expression levels of PPAR $\gamma 2$ and C/EBP $\alpha$ in 3T3-L1 adipocytes. Differentiated 3T3-L1 cells were treated with various concentrations of catechins and caffeine in combination, and harvested at days (A) 1, (B) 2, (C) 4 and (D) 8 . Alterations in the gene expression of PPAR $\gamma 2$ and $\mathrm{C} / \mathrm{EBP} \alpha$ were measured by reverse transcription-quantitative polymerase chain reaction. Data are presented as the

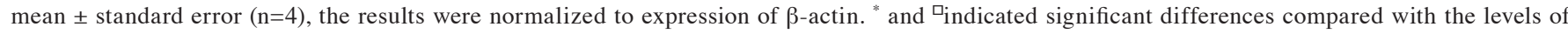
control $(\mathrm{P}<0.05)$. PPAR, peroxisome proliferator-activated receptor; C/EBP, CCAAT/enhancer-binding protein; I, $40 \mu \mathrm{g} / \mathrm{ml}$ catechins; II, $160 \mu \mathrm{g} / \mathrm{ml}$ caffeine; III, control; IV, $80 \mu \mathrm{g} / \mathrm{ml}$ caffeine $+10 \mu \mathrm{g} / \mathrm{ml}$ catechins; V, $160 \mu \mathrm{g} / \mathrm{ml}$ caffeine $+10 \mu \mathrm{g} / \mathrm{ml}$ catechins; VI, $80 \mu \mathrm{g} / \mathrm{ml}$ caffeine $+20 \mu \mathrm{g} / \mathrm{ml}$ catechins; VII, $160 \mu \mathrm{g} / \mathrm{ml}$ caffeine $+20 \mu \mathrm{g} / \mathrm{ml}$ catechins; VIII, $80 \mu \mathrm{g} / \mathrm{ml}$ caffeine $+40 \mu \mathrm{g} / \mathrm{ml}$ catechins; IX, $160 \mu \mathrm{g} / \mathrm{ml}$ caffeine $+40 \mu \mathrm{g} / \mathrm{ml}$ catechins .

the effect demonstrated in vitro in the present study, and the combination revealed a synergistic effect.

It has been shown that the adipocyte differentiation process involves the expression of a series of adipocyte-specific genes, which are synergistically regulated by $P P A R \gamma$ and $C / E B P \alpha(30)$. It has been demonstrated that the PPAR 2 gene, which is more abundantly expressed in the adipose tissues than PPAR 1 , has a critical role in adipocyte differentiation and adipogenesis, and exogenous PPAR 2 is able to reactivate adipogenesis (31). In the present study, in 3T3-L1 cells exposed to the combination of catechins and caffeine, $P P A R \gamma 2$ and $C / E B P \alpha$ levels were significantly suppressed in groups I, V, VII, VIII and IX on the fourth day, which subsequently changed to groups I, VIII and IX at the eighth day of 
A
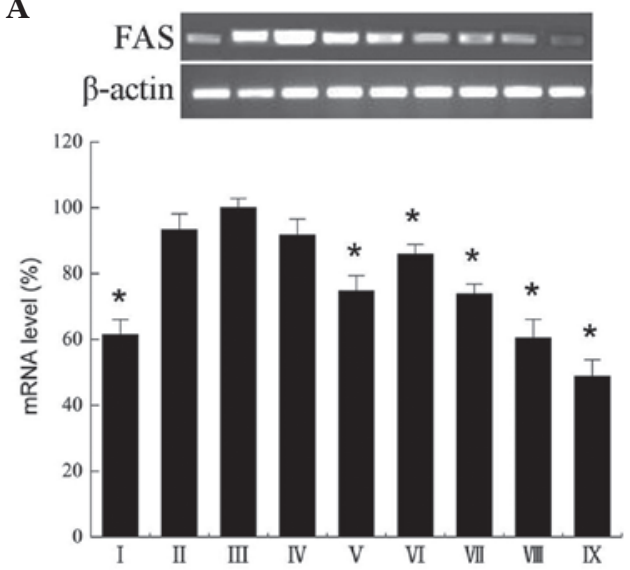

B
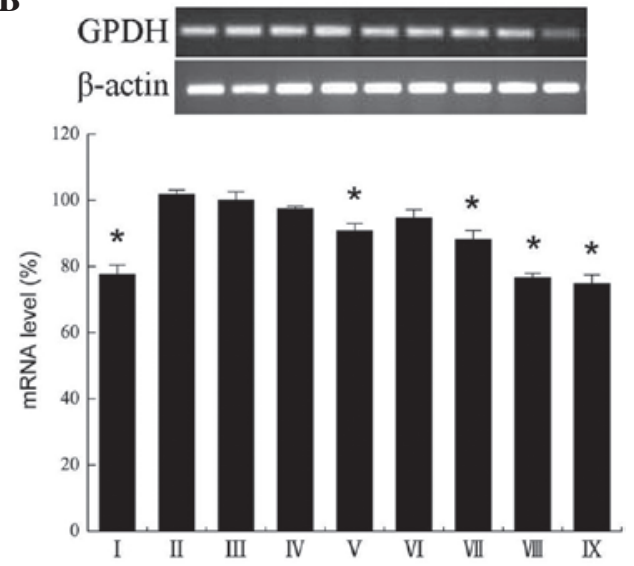

Figure 3. Effects of combination therapy with catechins and caffeine on mRNA expression relative to lipogenesis. Differentiated 3T3-L1 cells were treated with various concentrations of catechins and caffeine in combination, and harvested at day 8. Gene expression levels of (A) FAS and (B) GPDH were measured by reverse transcription-quantitative polymerase chain reaction. Data are presented as the mean \pm standard error $(n=4)$, and the results were normalized to the expression of $\beta$-actin. Different letters indicate samples that are significantly different ( $\mathrm{P}<0.05)$. FAS, fatty acid synthetase; GPDH, glycerol-3-phosphate dehydrogenase; I, $40 \mu \mathrm{g} / \mathrm{ml}$ catechins; II, $160 \mu \mathrm{g} / \mathrm{ml}$ caffeine; III, control; IV, $80 \mu \mathrm{g} / \mathrm{ml}$ caffeine $+10 \mu \mathrm{g} / \mathrm{ml}$ catechins; V, $160 \mu \mathrm{g} / \mathrm{ml}$ caffeine $+10 \mu \mathrm{g} / \mathrm{ml}$ catechins; VI, $80 \mu \mathrm{g} / \mathrm{ml}$ caffeine $+20 \mu \mathrm{g} / \mathrm{ml}$ catechins; VII, $160 \mu \mathrm{g} / \mathrm{ml}$ caffeine $+20 \mu \mathrm{g} / \mathrm{ml}$ catechins; VIII, $80 \mu \mathrm{g} / \mathrm{ml}$ caffeine $+40 \mu \mathrm{g} / \mathrm{ml}$ catechins; IX, $160 \mu \mathrm{g} / \mathrm{ml}$ caffeine $+40 \mu \mathrm{g} / \mathrm{ml}$ catechins.

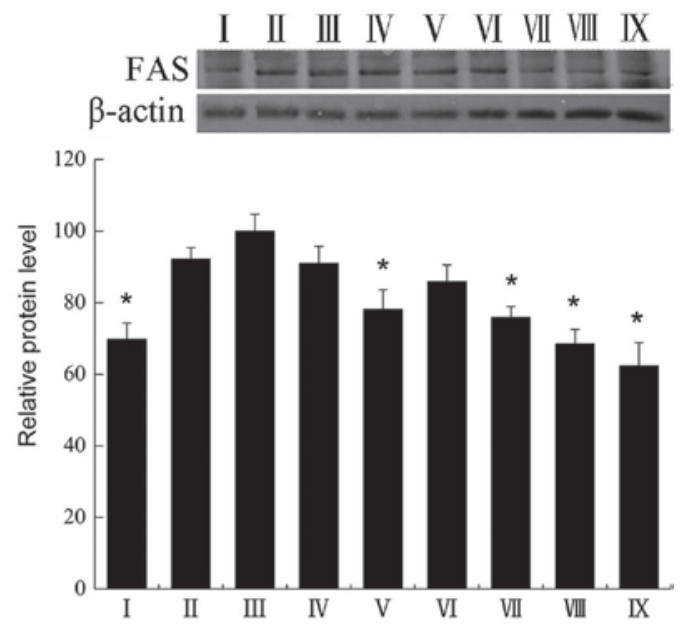

Figure 4. Effects of combination therapy with catechins and caffeine on protein expression levels of FAS in 3T3-L1 adipocytes. Differentiated 3T3-L1 cells were treated with various concentrations of catechins and caffeine in combination, and harvested at day 8 . Cell proteins were extracted and subjected to western blotting and densitometry analysis. Data are presented as the mean \pm standard error $(n=4)$ and protein levels were normalized to the expression of $\beta$-actin. ${ }^{*} \mathrm{P}<0.05$ ) with the control. FAS, fatty acid synthetase; I, $40 \mu \mathrm{g} / \mathrm{ml}$ catechins; II, $160 \mu \mathrm{g} / \mathrm{ml}$ caffeine; III, control; IV, $80 \mu \mathrm{g} / \mathrm{ml}$ caffeine $+10 \mu \mathrm{g} / \mathrm{ml}$ catechins; $\mathrm{V}, 160 \mu \mathrm{g} / \mathrm{ml}$ caffeine $+10 \mu \mathrm{g} / \mathrm{ml}$ catechins; VI, $80 \mu \mathrm{g} / \mathrm{ml}$ caffeine $+20 \mu \mathrm{g} / \mathrm{ml}$ catechins; VII, $160 \mu \mathrm{g} / \mathrm{ml}$ caffeine $+20 \mu \mathrm{g} / \mathrm{ml}$ catechins; VIII, $80 \mu \mathrm{g} / \mathrm{ml}$ caffeine $+40 \mu \mathrm{g} / \mathrm{ml}$ catechins; IX, $160 \mu \mathrm{g} / \mathrm{ml}$ caffeine $+40 \mu \mathrm{g} / \mathrm{ml}$ catechins.

differentiation. PPAR $\gamma$ ligands are exclusively involved in cell differentiation during the first four days in 3T3-L1 cells (32). 3T3-L1 cells treated with $100 \mu \mathrm{M}$ EGCG, noticeably downregulated the mRNA expression levels of $P P A R \gamma$ and $C / E B P \alpha$ at day 8 in a previous study (33). Whereas, $5 \mu \mathrm{M}$ EGCG treatment during the early stage of cell differentiation enhanced mRNA expression of $P P A R \gamma 2$, but did not affect $C / E B P \alpha$ gene expression (34); thus the concentration and times of treatment administration may be responsible for the difference.

FAS and GPDH are associated with fat synthesis, and have been demonstrated to increase their levels 10-100 fold during adipocyte differentiation (35). GPDH is a key intracellular enzyme in the conversion of glycerol to TG in the lipid synthesis pathway (36); its increased activity was demonstrated to be positively associated with the degree of adipocyte differentiation, which is measured as an indicator of differentiation (37). Catechins and catechins + caffeine remarkably inhibited the mRNA expression levels of $F A S$ and $G D P H$ at day 8 in the present study. These results suggest that catechins and caffeine in combination concertedly suppressed adipogenesis through the downregulation of the genes expression of transcriptional factors and adipogenesis-related enzymes.

Consistent with the FAS mRNA expression levels demonstrated, FAS protein expression decreased in a dose-dependent manner after treatment with catechins and caffeine in combination. Fat is coordinated through lipogenesis and lipolysis, and full hydrolysis depends on the activity of ATGL, HSL and monoacylglycerol lipase (38). ATGL, which is highly expressed in white adipose tissue and is involved in triglyceride-specific hydrolysis (39), and HSL have an important role in lipid metabolism, particularly in hydrolyzing diglyceride and monolglyceride (40). Recent studies have shown that ATGL and HSL are activated simultaneously, in order to allow HSL access to the lipid droplet and meanwhile permit the stimulation of ATGL (41). Catecholamines, including NA, adrenaline and dopamine, are important regulatory factors of adipose tissue lipolysis, combined with $\beta$-receptors to promote lipid metabolism (42). Catecholamine-induced lipolysis has shown that lipid droplets shrink in mature adipocytes and that small lipid droplets develop in almost all cells (43). In the present study, the addition of NA notably increased both ATGL and HSL protein expression levels. It has been demonstrated that catecholamines are able to function in receptors on the surface to activate lipolysis, promote cAMP synthesis and activate PKA pathway, in order to phosphorylate HSL and perilipin (44). In vitro experiments have indicated that phosphorylation of HSL may induce conformational changes; notable, activity increased by $\sim 100 \%$ by exposing and/or increasing HSL lipid 
A
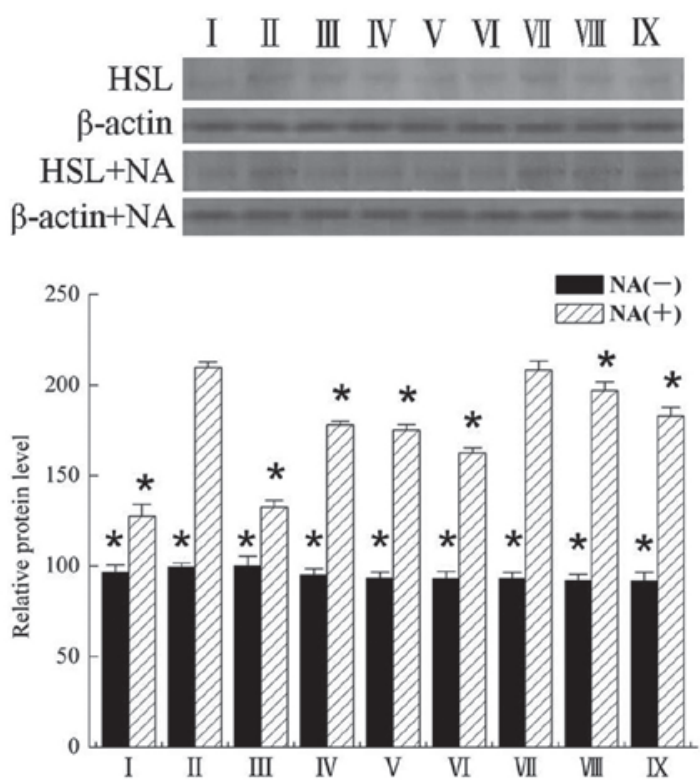

B
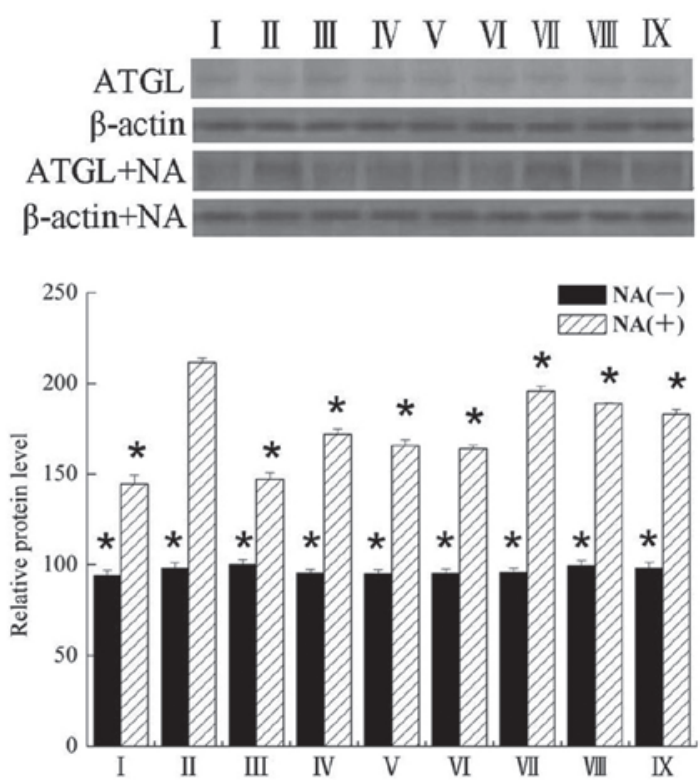

Figure 5. Effects of combination therapy with catechins and caffeine on protein expression levels relative to lipolysis in 3T3-L1 adipocytes. Differentiated 3T3-L1 cells were treated with various concentrations of catechins and caffeine in combination, and harvested at day 13 . Cell proteins were extracted and subjected to western blotting and densitometry analysis to determine (A) HSL and (B) ATGL protein expression levels. Data are presented as the mean \pm standard error $(n=4)$ and protein levels were normalized to the expression of $\beta$-actin. Letters with different superscripts indicate samples that are significantly different $\left({ }^{*} \mathrm{P}<0.05\right)$ with the control. HSL, hormone sensitive lipase; ATGL, adipose triglyceride lipase; NA, noradrenaline; I, $40 \mu \mathrm{g} / \mathrm{ml}$ catechins; II, $160 \mu \mathrm{g} / \mathrm{ml}$ caffeine; III, control; IV, $80 \mu \mathrm{g} / \mathrm{ml}$ caffeine $+10 \mu \mathrm{g} / \mathrm{ml}$ catechins; V, $160 \mu \mathrm{g} / \mathrm{ml}$ caffeine $+10 \mu \mathrm{g} / \mathrm{ml}$ catechins; VI, $80 \mu \mathrm{g} / \mathrm{ml} \mathrm{caffeine}+20 \mu \mathrm{g} / \mathrm{ml}$ catechins; VII, $160 \mu \mathrm{g} / \mathrm{ml}$ caffeine $+20 \mu \mathrm{g} / \mathrm{ml}$ catechins; VIII, $80 \mu \mathrm{g} / \mathrm{ml}$ caffeine $+40 \mu \mathrm{g} / \mathrm{ml}$ catechins; IX, $160 \mu \mathrm{g} / \mathrm{ml}$ caffeine $+40 \mu \mathrm{g} / \mathrm{ml} \mathrm{catechins}$.

binding region in a previous study (45). Moreover, phosphorylated perilipin spur comparative gene identification-58 into the cytoplasm to integrate with ATGL, activating ATGL and lipolysis (46). It has also been demonstrated that the enhancement of catecholamine induces lipolysis in adipocytes treated with AICAR for 8 weeks, accompanied by the increased protein expression of ATGL and periilipin in fat depots (47). In the present study, combination therapy with catechins and caffeine markedly increased the protein levels of ATGL and HSL induced by NA, thereby inhibiting fat accumulation in 3T3-L1 cells.

In conclusion, the findings of the present study showed that combination therapy with catechins and caffeine inhibited fat deposition by inhibiting the mRNA expression of transcriptional factors and adipogenesis-related enzymes, and enhancing the protein expression of lipolysis-related enzymes in the presence of NA in 3T3-L1 cells. These results indicate that the use of catechins and caffeine in combination may be considered as potential candidate for the regulation of obesity and lifestyle-related disease.

\section{Acknowledgements}

The present study was kindly supported by the National Natural Science Foundation of China (grant no. 31160320) and the Jiangxi Province Natural Science Foundation of China (grant no. 20142BAB204003).

\section{References}

1. Aranceta Bartrina J: Public health and the prevention of obesity: Failure or success? Nutr Hosp 28 (Suppl 5): S128-S137, 2013.
2. Kong XM, Zhang XL, Zhao Q, He J, Chen L, Zhao ZG, Li Q, Ge JP, Chen G, Guo XH, et al: Obesity-related genomic loci are associated with type 2 diabetes in a Han Chinese population. PLoS One 9: e104486, 2014.

3. Park S, Kim Y, Shin HR, Lee B, Shin A, Jung KW, Jee SH, Kim DH, Yun YH, Park SK, et al: Population-attributable causes of cancer in Korea: Obesity and physical inactivity. PLoS One 4: e90871, 2014.

4. Sujana SG and Robert HM: Hypertension in children with obesity. World J Hypertens 4: 15-24, 2014.

5. Zhang Y, Liu J, Yao J, Ji G, Qian L, Wang J, Zhang G, Tian J, Nie Y,Zhang Y, et al: Obesity: Pathophysiology and intervention. Nutrients 6: 5153-5183, 2014.

6. Dave S, Kaur NJ, Nanduri R, Dkhar HK, Kumar A and Gupta P: Inhibition of adipogenesis and induction of apoptosis and lipolysis by stem bromelain in 3T3-L1 adipocytes. PLoS One 7: e30831, 2012.

7. Mannucci E, Dicembrini I, Rotella F and Rotella CM: Orlistat and sibutramine beyond weight loss. Nutr Metab Cardiovas 18: 342-348, 2008.

8. Oberholzer HM, van der Schoor C and Bester MJ: Sibutramine, a serotomin-norepinephrine reuptake inhibitor, causes fibrosis in rats. Environ Toxicol Phar 40: 71-76, 2015.

9. Rayalam S, Della-Fera MA and Baile CA: Phytochemicals and regulation of the adipocyte life cycle. J Nutr Biochem 19: 717-726, 2008.

10. Lim DW, Kim JG and Kim YT: Effects of dietary isoflavones from Puerariae radix on lipid and bone metabolism in ovariectomized rats. Nutrients 5: 2734-2746, 2013.

11. Zheng GD, Lin LZ, Zhong SS, Zhang QF and Li DM: Effects of puerarin on lipid accumulation and metabolism in high-fat diet-fed mice. PLoS One 10: e0122925, 2015.

12. Spiegeman BM and Filer JS: Adipogenesis and obesity: Rounding out the big picture. Cell 87: 377-389, 1996.

13. Kim EY, Kim WK, Oh KJ, Han BS, Lee SC and Bae KH: Recent advances in proteomic studies of adipose tissues and adipocytes. Int Mol Sci 16: 4581-4599, 2015.

14. Poulos SP, Dodson MV and Hausman GJ: Cell line models for differentiation: Preadipocytes and adipocytes. Exp Biol Med (Maywood) 235: 1185-1193, 2010.

15. Zeng JL, Li ZH, Wang ZC and Zhang HL: Green tea consumption and risk of pancreatic cancer: A meta-analysis. Nutrition 6: 4640-4650, 2014. 
16. Zheng XX, Xu YL, Li SH, Liu XX, Hui R and Huang XH: Green tea intake lowers fasting serum total and LDL cholesterol in adults: A meta-analysis of 14 randomized controlled trials. Am J Clin Nutr 94: 601-610, 2011.

17. Vieira Senger AE, Schwanke CH, Gomes I and Valle Gottlieb MG: Effect of green tea (Camellia sinensis) consumption on the components of metabolism syndrome in elderly. J Nutr Health Aging 16: 738-742, 2012.

18. Choung MG, Hwang YS, Lee MS, Lee J, Kang ST and Jun TH: Comparison of extraction and isolation efficiency of catechins and caffeine from green tea leaves using different solvent systems. Int J Food Sci Tech 49: 1572-1578, 2014.

19. Di LC, Dell'Agli M, Sanqiovanni E, Dos Santos A, Uberti F, Moro E, Bosisio E and Restani P: Correlation between catechin content and NF- $\kappa \mathrm{B}$ inhibition by influsion of green tea and black tea. Plant Foods Hum Nutr 68: 149-154, 2013.

20. Hursel R and Westerterp-Plantenqa MS: Catachin- and caffeine-rich teas for control of body weight in humans. Am J Clin Nutr 98 (6 Suppl): S1682-S1693, 2013.

21. Chan PT, Fong WP, Cheung YL, Huang WK and Chen ZY: Jasmine green tea epicatechins are hypolipidemic in hamsters (Mesocricetus auratus) fed a high fat diet. J Nutr 129: 1094-1101, 1999.

22. Hughes LA, Arts IC, Ambergen T, Brants HA, Daqnelie PC, Goldbohm RA, van den Brandt PA and Weijenberq MP Netherlands Cohort Study: Higher dietary flavone, flavonol, and catechin intakes are associated with less of an increase in BMI over time in women: A longitudinal analysis from the Netherlands cohort study. Am J Clin Nutr 88: 1341-1352, 2008.

23. Dulloo AG, Seydoux J, Girardier L, Chantre $P$ and Vandermander J: Green tea and thermogenesis: Interactions between catechin-polyphenols, caffeine and sympathetic activity. Int J Obes Relat Metab Disord 24: 252-258, 2000.

24. Zheng G, Sayama K, Okubo T, Juneja LR and Oguni I: Anti-obesity effects of three major components of green tea, catechins, caffeine and theanine, in mice. In Vivo 18: 55-62, 2004.

25. Dulloo AG, Duret C, Rohrer D, Girardier L, Mensi N, Fathi M, Chantre $\mathrm{P}$ and Vandermander J: Efficacy of a green tea extract rich in catechin polyphenols and caffeine in increasing $24-h$ energy expenditure and fat oxidation in humans. Am J Clin Nutr 70: 1040-1045, 1999.

26. Livak KJ and Schmittgen TD: Analysis of relative gene expression data using real-time quantitative PCR and the $2^{-\Delta \Delta C}$ method. Methods 25: 402-408, 2001.

27. Lee JH, Kim T, Lee JJ, Kim HK, Yun N, Jeon J, Kim SK and Ma JY: The herbal medicine KBH-1 inhibits fat accumulation in 3T3-L1 adipocytes and reduces high fat diet-Induced obesity through regulation of the AMPK pathway. PLoS One 10 e142041, 2015

28. Lee MS, Kim CT, Kim IH and Kim Y: Inhibitory effects of green tea catechin on the lipid accumulation in 3T3-L1 adipocytes Phytother Res 23: 1088-1091, 2009.

29. Murosaki S, Lee TR, Muroyama K, Shin ES, Cho SY, Yamamoto Y and Lee SJ: A combination of caffeine, arginine, soy isoflavones, and L-carnitine enhances both lipolysis and fatty acid oxidation in 3T3-L1 and HepG2 cells in vitro and in KK mice in vivo. J Nutr 137: 2252-2257, 2007.

30. Salma N, Xiao H and Imbalzano AN: Temporal recruitment of CCAAT/enhancer-binding proteins to early and late adipogenic promoters in vivo. J Mol Endocrinol 36: 139-151, 2006.

31. Takenaka Y, Ikuo I, Nakano T, Shinoda Y, Ikeda M, Awata T and Katayama S: A novel splicing variant of peroxisome proliferator activated receptor- $\gamma$ (Ppar $\gamma 1 \mathrm{sv})$ cooperatively regulates adipocyte differentiation with Ppar $\gamma ; 2$. PLoS One 8: e65583, 2013.
32. Madsen L,Petersen RK, Sørensen MB, Jørgensen C, Hallenborg P, Pridal L, Fleckner J, Amri EZ, Krieg P, Furstenberger G, et al: Adipocyte differentiation of 3T3-L1 preadipocytes is dependent on lipoxygenase activity during the initial stages of the differentiation process. Biochem J 375: 539-549, 2003.

33. Kim H and Sakamoto K: (-)-Epigallocatechin gallate suppresses adipocyte differentiation through the MEK/ERK and PI3K/Akt pathways. Cell Biol Int 36: 147-153, 2012.

34. Sakurai N, Mochizuki K, Kameji H, Shimada M and Goda T: (-)-Epigallocatechin gallate enhances the expression of genes related to insulin sensitivity and adipocyte differentiation in 3T3-L1 adipocytes at an early stage of differentiation. Nutrition 25: 1047-1056, 2009.

35. Choi Y, Kim Y, Ham H, Park Y, Jeong HS and Lee J: Nobiletin suppresses adipogenesis by regulating the expression of adipogenic transcription factors and the activation of AMP-activated protein kinase (AMPK). J Agric Food Chem 59: 12483-12849, 2011.

36. Wise LS and Green H: Participation of one isozyme of cytosolic glycerophosphate dehydrogenase in the adipose conversion of 3T3 cells. J Biol Chem 25: 273-275, 1979.

37. Lee EJ, Moon JY and Yoo BS: Cadmium inhibits the differentiation of 3T3-L1 preadipocyte through the C/EBP $\alpha$ and PPAR $\gamma$ pathways. Drug Chem Toxicol 35: 225-231, 2012

38. Shen WJ, Patel S, Miyoshi H, Greenberg AS and Kraemer FB: Functional interaction of hormone-sensitive lipase and lipase and perilipin in lipolysis. J Lipid Res 50: 2306-2313, 2009.

39. Bolsin-Lopes A and Alonso-Vale MI: Lipolysis and lipases in white adipose tissue - An update. Arch Endocrinol Metab 59: 335-342, 2015.

40. Kershaw EE, Hamm JK, Verhagen LA, Peroni O, Katic M and Flier JS: Adipose triglyceride lipase: Function, regulation by insulin, and comparison with adiponutrin. Diabetes 55: 148-157, 2006.

41. Chaves VE, Frasson D and Kawashita NH: Several agents and pathways regulate lipolysis in adipocytes. Biochimie 93: 1631-1640, 2011.

42. Barbe P, Millet L, Galitzky J, Lafontan M and Berlan M: In situ assessment of the role of the beta 1-, beta 2- and beta 3 -adrenoceptors in the control of lipolysis and nutritive blood flow in human subcutaneous adipose tissue. Br J Pharmacol 117: 907-1013, 1996

43. Nagayama M, Shimizu K, Taira T, Uchida T and Gohara K: Shrinking and development of lipid droplets in adipocytes during catecholamine-induced lipolysis. FEBS Lett 584: 86-92, 2010.

44. Yamaquchi T, Omatsu N, Matsushita S and Osumi T: CGI-58 interacts with perilipin and is localized to lipid droplets. Possible involvement of CGI-58 mislocalization in Chanarin-Dorfman syndrome. J Biol Chem 279: 30490-30497, 2004.

45. Wueest S, Yang X, Liu J, Schoenle EJ and Konrad D: Inverse regulation of basal lipolysis in perigonadal and mesenteric fat depots in mice. Am J Physiol Endocrinol Metab 302: E153-E160, 2012.

46. Granneman JG, Moore HP, G ranneman RL, Greenberq AS, Obin MS and Zhu Z: Analysis of lipolytic protein trafficking andinteractions in adipocytes. J Biol Chem 282: 5726-5735, 2007.

47. Gaidhu MP, Bikopoulos G and Ceddia RB: Chronic AICAR-induced AMP-kinase activation regulates adipocyte lipolysis in a time-dependent and fat depot-specifit manner in rats. Am J Physiol Cell Physiol 303: C1192-C1197, 2012. 